\title{
The Leadership of Schools on Work Motivation in the Digital Era
}

\author{
Dera Elfranita ${ }^{*}$, Nur Ahyani ${ }^{2}$, Dessy Wardiah ${ }^{2}$ \\ ${ }^{1}$ SMA Negeri 6 OKU \\ ${ }^{2}$ Universitas PGRI Palembang \\ ${ }^{*}$ Corresponding author. Email: elfranitadera@yahoo.com
}

\begin{abstract}
Education in the era of the industrial revolution 4.0 has undergone various changes, one of which is leadership style. The principal was asked to adjust to the demands of the industrial revolution 4.0 era. The leadership of the principal plays a significant role in increasing work motivation. In the digital era, there are opportunities and challenges that must be faced to improve the quality of education. Quality improvement is something that we cannot avoid. This study uses a qualitative approach with a literature method. We found in the digital era, the principal must prepare schools to face the challenges and opportunities of the existing industrial revolution. For that, we need the right leadership in optimizing human resources. Increasing human resources must be accompanied by work motivation. Good work motivation will improve teacher performance. The principal must be able to generate strength, move, encourage, and give direct motivation to the colleagues.
\end{abstract}

Keywords: Principal Leadership, Work Motivation, Digital Era

\section{INTRODUCTION}

Advances in technology allow automation in almost all fields. The overall pattern of life and social interactions has changed due to the invasion of technology and new approaches [1]. Humans live in uncertainty globally due to a phase of the technological revolution that we call Industry 4.0. Industry 4.0 requires humans to have the skills to predict a very fast changing future. Every country must respond to these changes in an integrated and comprehensive manner. This response involves all global political stakeholders, from the public, the private sector, academia to civil society. The challenges we face in Industry 4.0 present opportunities. Walter identifies industry 4.0 challenges, consists of limitation of adequate skills, information technology security issues, reliability and stability of production machines, reluctance to change by stakeholders, and the loss of many jobs due to turning into automation.

The challenges of vocational education are increasingly complex with industry 4.0. Answering this challenge needs to be made changes and adjustments in schools. This change starts with the school leader. The leadership of the principal must be able to direct the school to answer the existing challenges. One of the focuses is teacher motivation in the context of personality formation and improving the quality of human resources.

One of the factors that have an essential role in forming personality and improving the quality of human resources is education. Support from the government and stakeholders in education is needed in order to create a quality and reliable quality of education as an effort to produce good, virtuous students as the successor of this nation's baton [3][4][5][6][7]. In carrying out its main duties and functions, teachers have a very important and central role and function in creating good quality education. Teachers as professional educators have the task of planning and carrying out learning, providing value, carrying out guidance to students, and community service in the surrounding environment. The commune as a role model for the surrounding community in good attitude and behavior. In order to achieve this, it takes indepth efforts by having several abilities and skills as one of the requirements to become a professional teacher which is commonly referred to as teacher competence. This ability absolutely must be possessed by professional teachers in educating the life of the nation and the state.

Within the school, teachers are led by the principal, who plays an important role because the principal has the 
responsibility to process and direct teachers to improve their performance in teaching [8][9][10][11]. Thus, principals are required to have their own ways of interacting with teachers that impact success in leading schools. In addition, it also provides role models for teachers and students in learning activities [12]. The principal is a determinant of success in a school organization based on what is expected. His. His duties and functions are very hard, so it is necessary to have good stakeholders on the scope of education to achieve the desired goals together. The implementation of daily tasks of teachers in the first step must be accompanied by a clear vision and mission organization [13][14][15][16].

As a support for the progress of education, especially in facilities and infrastructure, the government provides assistance in the form of funds to schools so that all components in the school can manage them as best as possible. The impact of this began to appear the principal's desire to project existing projects rather than their main tasks, namely, as individuals who carry out the success of education itself. Therefore, it is hoped that the principal does not lose track and direction of goals but remains based on the existing vision and mission.

The principal has a role as a leader in every educational institution and must be able to think about the relationship between education and development and technological progress coupled with an increase in knowledge so that there is a need for work motivation or work motivation in that flow. Suppose, in fact, and the teaching staff is unable to adapt to the demands of changes in development, science, and technology in carrying out learning. In that case, the principal must encourage so that each teacher is able to improve the quality of their knowledge. This motivation can be in the form of praise, gifts, or it can be in the form of cautions and warnings for educators who are negligent in their duties [17][18][19][20]. Based on the explanation described above, the writer wishes to research the title leadership of work motivation in the digital era.

\section{METHODS}

This research uses a qualitative approach and literary methods. Qualitative research is used to analyze existing theories [20]. We conducted a literature review by looking at existing problems and strengthened by previous studies related to the leadership style of school in Industry 4.0 ?

\section{RESULTS AND DISCUSSION}

A good principal is a principal who has leadership traits and behaviors that can create a good school climate and provide higher job satisfaction for teachers or subordinates. In his role as a leader, the principal must be able to direct others to do the tasks he wants and be fun for teachers at work. A good leader is able to pay attention to the needs and goals of the people who work for him (subordinates) who are not focused on their power so that subordinates' job satisfaction is always fulfilled. The principal is a leader figure who is ready to work intensively and is able to foster and guide teachers, and must always foster enthusiasm and motivation in order to create a harmonious relationship between the leader and the leader, thereby increasing the high quality of work so that good performance will be created [21].

The transformational leadership style has a positive and significant influence on work, like discipline. One's leadership determines the high work discipline with the style that is applied, namely transformational [22]. Meanwhile, the autocratic leadership style also has a positive and significant effect on work discipline. This finding means that leaders who adopt an autocratic leadership style have good work discipline. Leadership is defined so that it can influence someone to achieve their desires and a process to encourage subordinates.

A leader has at least three leadership components to lead people with different backgrounds and characteristics. The three components include transformational leadership, transactional leadership, and autocratic leadership. A leader strives so that his subordinates have excellent discipline. If his subordinates have a good level of discipline, they can be called effective and influential in leading an organization. Exemplary leadership is very influential on employee discipline. This is because a leader makes an example by his subordinates.

Leaders must set a good example, be well-disciplined, honest, fair, and in accordance with their actions. With a good leadership role model, the discipline of subordinates will also be good [5]. A person will be willing to obey and obey all rules and carry out duties either voluntarily or forced by discipline. Discipline means when the teacher always comes home on time, carries out his duties and responsibilities properly, obeys all the school rules, and the social norms/rules that apply in society.

Motivation is a factor that leads to behavior in organizations. Motivation comes from the word motive. Motive is a state in a person that creates strength, moves, encourages, and directs motivation. Motivation is a condition in a person's personality that encourages the individual to carry out certain activities to achieve a goal [23]. Thus, motivation is a factor that exists in a person that drives his behavior to fulfill certain goals. In practice, an employee who has high work motivation, he also tends to have a good and high performance.

Someone who creates strength, moves, encourages, directs motivation. Motivation is a condition in a person's personality that encourages the individual to carry out 
certain activities to achieve a goal [24]. Work motivation is a factor that exists in a person that drives his behavior to fulfill certain goals. In practice, an employee who has high work motivation, he or she also tends to have good and high performance [25].

Teacher performance can optimize if the various components involved in the educational process can play an optimal role in achieving the stated goals. Several internal factors that can affect teacher performance include education level, skills, discipline, attitudes and work ethics, motivation, health level, income, and achievement opportunities. While other aspects (external factors) that affect teacher performance are leadership, technology, management, government policies, environment, organizational culture, and work climate. Teacher work motivation is a factor that can affect teacher performance because work motivation is a stimulant that arouses teachers' passion for work. Teacher performance will be good if there are stimulate that generate motivation, both internal and external motivation [25][26]. Motivation will lead to positive things if it affects teacher satisfaction and vice versa. If it leads to negative things it will have an effect on dissatisfaction.

Teachers without job satisfaction cannot be expected to be highly committed to the organization. There is a tendency for teachers to shy away from their work, such as not involving themselves in work, not being enthusiastic about teaching, rejecting organizational policies and values. It may even happen that the teacher switches to another job or another organization if there is a promising opportunity. Based on the explanation above, teacher performance is closely related to teacher work motivation. Thus, work motivation is an important element in improving teacher performance and human resources. In general, motivation is defined as an encouragement both from within (intrinsically) and from outside (extrinsic) so that teachers will work hard, sincerely and thoroughly and are oriented towards the quality of work results.

Many experts state that Indonesian human resources are "lazy" [27]. In the sense that there is less drive to work harder and less quality oriented. In addition to work motivation factors, to improve teacher performance, it is also necessary to increase school principals' leadership. The results of the study by several experts indicate that the leadership style in every organization is a factor related to teacher performance, organization and organizational effectiveness. There are several determinants of work teacher performance, including leadership, climate, type of leadership, leaders from 33 other influencing factors. Against this opinion, it can be concluded that the principal's leadership has an effect on teacher performance [28].
We found that the teacher performance problems and the quality of learning, especially in assessing learning outcomes and applying research results in the learning, are still low. In addition, timeliness in applying new things and providing new things in learning is not like expected. We also found the teacher initiative at work, especially in using various learning methods, which not all teachers do. The problem of teacher work motivation, especially at the level of internal motivation, is career progression and achievement drive. Most teachers are still classified as low and at the level of external motivation, especially working conditions in general are still classified as uncomfortable due to the high political temperature, unstable policy changes, and the accumulation of teacher workloads.

Principal leadership problems include; first, not all school principals treat school organizations as a totality by placing all organizational units in schools that are led in the right roles and proportions. Second, not all school principals have provided opportunities for subordinates to participate in the decision-making process. Third, not all principals are open to others' ideas, views, and suggestions, including their subordinates. Teacher work motivation is measured according to the opinion or view of the teacher, especially with regard to internal motivation, consisting of: encouragement to work, advancement in career, recognition gained, sense of responsibility at work, interest in assignments, and drive for achievement. External motivation consists of interpersonal relationships, payroll/honorarium, supervision of the principal, and working conditions. The principal's democratic leadership is measured according to the teacher's opinion or view, including loyalty to the organization, exemplary behavior, delegation of duties and responsibilities to subordinates, and collective decision-making. Teacher performance is measured by the teacher's opinion or view, including quality of work, speed/punctuality, initiative in work, work ability, and communication.

Many factors influence the teachers performance, including principal leadership and work motivation, which are essentially the result of the interaction between these various factors, including principal leadership and work motivation [29]. Thus the principal's leadership and work motivation jointly influence teacher performance. The better the principal leadership and work motivation, the better the teacher's performance.

\section{CONCLUSION}

In the digital era, the principal must prepare schools to face the existing industrial revolution's challenges and opportunities. For that, we need the right leadership in optimizing human resources. Increasing human resources must be accompanied by work motivation. Good work 
motivation will improve teacher performance. The principal must be able to generate strength, move, encourage, direct motivation.

\section{REFERENCES}

[1] Tjandrawina, R.R. (2016). Industri 4.0: Revolusi industri abad ini dan pengaruhnya pada bidang kesehatan dan bioteknologi. Jurnal Medicinus, 29(1)

[2] Sung, T.K. (2017). Industri 4.0: A Korea perspective. Technological Forecasting and Social Change Journal, 1-6.

[3] Slameto. (2010). Belajar dan Faktor-Faktor Yang Mempengaruhi. Jakarta: Rineka Cipta.

[4] Fitria, H., Mukhtar, M., \& Akbar, M. (2017). The Effect of Organizational Structure and Leadership Style on Teacher Performance In Private Secondary School. IJHCM (International Journal of Human Capital Management), 1(02), 101-112.

[5] Kristiawan, M., Yuniarsih, Y., \& Fitria, H. (2019). Supervisi Pendidikan. Bandung: Alfabeta

[6] Sayer, I. M., Kristiawan, M., \& Agustina, M. (2018). Fairy Tale as a Medium for Children's Character Cooperation Building. Al-Ta lim Journal, 25(2), 108-116.

[7] Kristiawan, M., \& Tobari. (2017). The Characteristics of the Full Day School Based Elementary School. Transylvanian Review, 1(1).

[8] Kristiawan, M., \& Tobari. (2017). The Characteristics of the Full Day School Based Elementary School. Transylvanian Review, 1(1).

[9] Andriani, S., Kesumawati, N., \& Kristiawan, M. (2018). The Influence of the Transformational Leadership and Work Motivation on Teachers Performance. International Journal of Scientific \& Technology Research, 7(7).

[10] Salwa., Kristiawan, M., \& Lian, B. (2019). The Effect of Academic Qualification, Work Experience and Work Motivation towards Primary School Principal Performance. International Journal of Scientific \& Technology Research, 8(8)

[11] Murtiningsih, M., Kristiawan, M., \& Lian, B. (2019). The Correlation between Supervision of Headmaster and Interpersonal Communication With Work Ethos of the Teacher. European Journal of Education Studies.

[12] Djamarah, S. B. (2011). Strategi Balajar Mengajar. Jakarta. Rineka Cipta.
[13] Sriwahyuni, E., \& Kristiawan, M. (2019). Strategi Kepala Sekolah Dalam Mengimplementasikan Standar Nasional Pendidikan (SNP) Pada SMK Negeri 2 Bukittinggi. JMKSP (Jurnal Manajemen, Kepemimpinan, dan Supervisi Pendidikan), 4(1).

[14] Fitria, H. (2018). The Influence of Organizational Culture and Trust through the Teacher Performance In The Private Secondary School In Palembang. International Journal of Scientific \& Technology Research, 7(7)

[15] Fitria, H., Mukhtar, M., \& Akbar, M. (2017). The Effect of Organizational Structure and Leadership Style on Teacher Performance in Private Secondary School. IJHCM (International Journal of Human Capital Management), 1(02), 101-112.

[16] Yuliani, T., \& Kristiawan, M. (2017). Peran Kepemimpinan Kepala Sekolah dalam Membina Kompetensi Sosial (Pelayanan Prima) Tenaga Administrasi Sekolah. JMKSP (Jurnal Manajemen, Kepemimpinan, dan Supervisi Pendidikan), 1(2).

[17] Kristiawan, M., \& Tobari. (2017). The Characteristics of the Full Day School Based Elementary School. Transylvanian Review, 1(1).

[18] Kristiawan, M. (2016). Filsafat Pendidikan. Yogyakarta: Valia Pustaka.

[19] Kristiawan, M., Suryanti, I., Muntazir, M., \& Ribuwati, A. (2018). Inovasi Pendidikan. Jawa Timur: Wade Group National Publishing.

[20] Sugiyono. (2018). Metode Penelitian Manajemeb Pendekatan: kuantitatif, Kualitatif, Kombinasi (Mixed Methods), Penelitian Tindakan (Action Research), dan Penelitian Evaluasi. Bandung: Alfabeta.

[21] Mas'ud. (2017). Pengaruh Kompetensi Kepala Sekolah, Motivasi dan Kompetensi Guru terhadap Kinerja Guru serta Implikasinya pada Kompetens Lulusan. Jurnal Konfigensi, Vol. 5, No. 2

[22] Kadek, Y. (2015). Pengaruh Gaya Kepemimpinan terhadap Disiplin Kerja Pegawai di Dinas Balai Bahasa Provinsi Bali. Jurnal Universitas Udayana: Tidak Dipublikasikan.

[23] Hasibuan, M. (2012). Manajemen Sumber Daya Manusia. Jakarta: Bumi Aksara

[24] Handayani, T \& Rasyid, A. 2015. Pengaruh Kepemimpinan Kepala Sekolah, Motivasi Kerja dan Budaya Organisasi Sekolah Terhadap Kinerja Guru Pada SMAN di Kabupaten Wonosobo. Jurnal Akuntabilitas Manajemen Pendidikan, Vol. 3, No.2

[25] Kadir \& Mulyadi. (2019). Pengaruh Kepemimpinan Kepala Sekolah, Sarana Prasarana, dan Motivasi 
Kerja Guru Terhadap Kinerja Guru SMA. PEMBELAJAR: Jurnal Ilmu Pendidikan, Keguruan, dan Pembelajaran, Vol. 3, No. 2.

[26] Handayani, T \& Rasyid, A. 2015. Pengaruh Kepemimpinan Kepala Sekolah, Motivasi Kerja dan Budaya Organisasi Sekolah Terhadap Kinerja Guru Pada SMAN di Kabupaten Wonosobo. Jurnal Akuntabilitas Manajemen Pendidikan, Vol. 3, No.2

[27] Sriwahyuni, E., \& Kristiawan, M. (2019). Strategi Kepala Sekolah dalam Mengimplementasikan Standar Nasional Pendidikan (SNP) Pada SMK Negeri 2 Bukittinggi. JMKSP (Jurnal Manajemen, Kepemimpinan, dan Supervisi Pendidikan), 4(1).

[28] Suwarto, FX, \& Koeshartono, D. (2009). Budaya Organisasi Kajian Konsep dan Implementasi. Yogyakarta: Universitas Atma Jaya

[29] Mulyasa, E. (2007). Menjadi Kepala Sekolah Profesional. Bandung: PT Remaja Rosdakarya. 